\title{
Political economic origins of Sekondi-Takoradi, West Africa's new oil city
}

The origins, growth and trajectory of Sekondi-Takoradi, West Africa's newest oil city, are considered by using an "institutional-analytical" method of economic history. Particular attention is given to the role of ports, harbours and railways, and how they evolved and interacted with political economic institutions in the last 100 years. This omnibus historical analysis suggests that West Africa's newest oil city has come full circle. Its contemporary stat- ure in national and international circles has a historical parallel in the 1920s when, as now, it captured national, regional and international attention. The evidence suggests that contemporary narratives that strike a determinist relationship between resource boom and social doom need to be reconsidered.

Key words: ports, railways, oil, Ghana, Africa 


\section{Introduction}

Sekondi-Takoradi is West Africa's newest oil city. It is a twin city in Ghana. Black gold was discovered off its shores in 2007. By 2010, oil in commercial quantities was flowing in the city and, since 2011, oil has been leaving its shores in pursuit of international currency. This phase of the life of Sekondi-Takoradi has been accompanied by significant political and economic developments. The phenomenon of dollarising transactions in the city is intensifying as international oil magnates clamour for space in the city. Oil exploration and production have generated jobs in the city, led to the introduction of new courses and programs in the nation's universities and triggered much discussion in the nation's parliament and media outlets (McCaskie, 2008; Gyampo, 2011). Over a short period of time, "oil laws" have been enacted, "oil conferences" held and "oil committees and authorities" created (e.g., Kapela, 2009; Obeng-Odoom, 2009; Obeng-Odoom, 2012a). Physically, the city is receiving a facelift to welcome international guests and look like a centre of wealth creation. Indeed, for the first time, the streets in the city are being named (Consortium, 2011) and the descriptor "oil city" can be found engraved in many conspicuous sites in the city.

The attendant effects of this "oil fever" on the identity of the city have been similarly visible. Since 2007, when Sekondi-Takoradi's status as an "oil city" was announced, land and housing prices have risen by at least 200\% (Yalley \& Ofori-Darko, 2012). West African observers (e.g., Obeng-Odoom, 2009; Edem, 2011) predict even further reconfiguration of the city and its global status with further ramifications for access to and control of housing and land.

One prominent view among social scientists, especially those in sociology, is that these sudden changes tend to cause social breakdown or, in Emile Durkheim's terms, "anomie" (Durkheim, 1951). That is, boomtowns invariably collapse or experience total "social disruption" (Wilkinson et al., 1982; Lawrie et al., 2011). Orthodox economists strike a similar determinist relationship between resource boom and socio-economic and political doom with their concept of a "resource curse" that makes use of macroeconomic processes, such as volatility of oil prices and appreciation of local currency, and their concomitant effects as explanatory variables (Corden \& Neary, 1982; Collier, 2009). Political scientists use the notion of "rentier state" to argue that resource booms tend to make the state in a resource-rich country autocratic because it becomes overly dependent on resource rents and "people's power" ceases to determine the survival of the state (Beblawi, 1987).

It is important to consider whether the future of Sekondi-Takoradi will be as bleak. One way to do so is to analyse how the city began its life, grew and rose to fame through economic and political successes. Studies of the city that look at oil (see, e.g., Boohene \& Peprah, 2011; Yalley \& Ofori-Darko, 2012; Obeng-Odoom, 2012a, 2012b) have not been historical. Thus, this paper takes a step in that direction. It looks at the role of political and economic institutions in the origins and trajectory of Sekondi-Takoradi in the last 100 years, and it examines how the city experienced periods of sudden change and fame in the past. Such examination is important because trying to understand the present and reflecting on the future through examining the past helps provide insights for future research and public policy.

In doing so, this article uses an "institutional-analytical" method that engages historical details and records and relates them to broader social explanations embedded in which are the roles of political economic institutions and phenomena that are interlocking and interdependent (Tuma, 1971). This inductive approach entails critically assessing and synthesising micro- and macro-level qualitative and quantitative historical data. It simultaneously traverses and transcends the "economy", the "social" and the "polity" in accounting for the "economic" (Gay, 1930; Greif, 1998). Specifically, the method builds on 1) textual analysis (reading original texts to tease out the intent of the authors), 2) contextual analysis (ideas by taking into account the mood of the time period), 3) historical narrative (including critical synthesis of the stories in the past) and 4) rational reconstructions (such as re-reading old texts and making sense of them in a modern context; Marcuzzo, 2008).

This article shows that the rise, growth and trajectory of Sekondi-Takoradi, driven by its transport and trade subsectors, were shaped, constrained and restrained by the interactions of institutions locally, nationally and internationally in a process mediated by the agency of workers and activities of other social groups. From this perspective, it is argued that the "effect of oil" cannot happen as an "event". Instead, oil dynamics ooze through a complex web of social relations and institutional interactions. These findings suggest that narratives that posit a determinist relationship between sudden change, such as a resource boom, and "social disruption", "resource curse" or "rentier state" can be misleading. The ensuing sections discuss, in turn, economic origins, political consciousness and recent developments in Sekondi-Takoradi.

\section{Economic origins}

"Takoradi" and "Sekondi" are indigenised forms of the original Prussian names "Taccarary", and "Secundis". They were the names of two fishing settlements in the Gold Coast. ${ }^{[1]}$ The Prussians were some of the first foreigners to establish trade contact with Sekondi-Takoradi. Nevertheless, it was the Dutch 
that first settled in the city. In 1644, they built Fort Orange in Sekondi. Simultaneously, there were significant British influence and settlement in Sekondi, but in 1872 the Dutch left the area and sold their belongings to the British (Administrators, 2012). In turn, the political division between "Dutch Sekondi" and "British Sekondi" collapsed.

Purposeful public policy was put in place to ensure the growth of Sekondi-Takoradi. For instance, there was a policy to reduce the $25 \%$ income tax if investors established business entities in the city. In turn, Sekondi-Takoradi attracted many firms and, alone, contributed $21 \%$ of the total wood-processing firms in Ghana in the 1980s (Owusu, 1998). However, the city rose to fame primarily because of the role that transportation played in the city's economy. Nonetheless, road transport, which is the dominant mode of communication in the city today (Mahama, 2012), was not the type that prevailed during its formative years. The first road network built in the Gold Coast was the road from Saltpond to Oda. It was completed in 1895. There were only a few cars to make use of road networks around the time. Indeed, as of 1911, there were only 16 trucks and five cars in the Gold Coast, most of which were in Accra. However, the development of the country was rapid, and so other networks such as the road from Nsawam to Cape Coast to Sekondi were built in anticipation of an increase in the number of cars in the country (Ministry of Education, 1991).

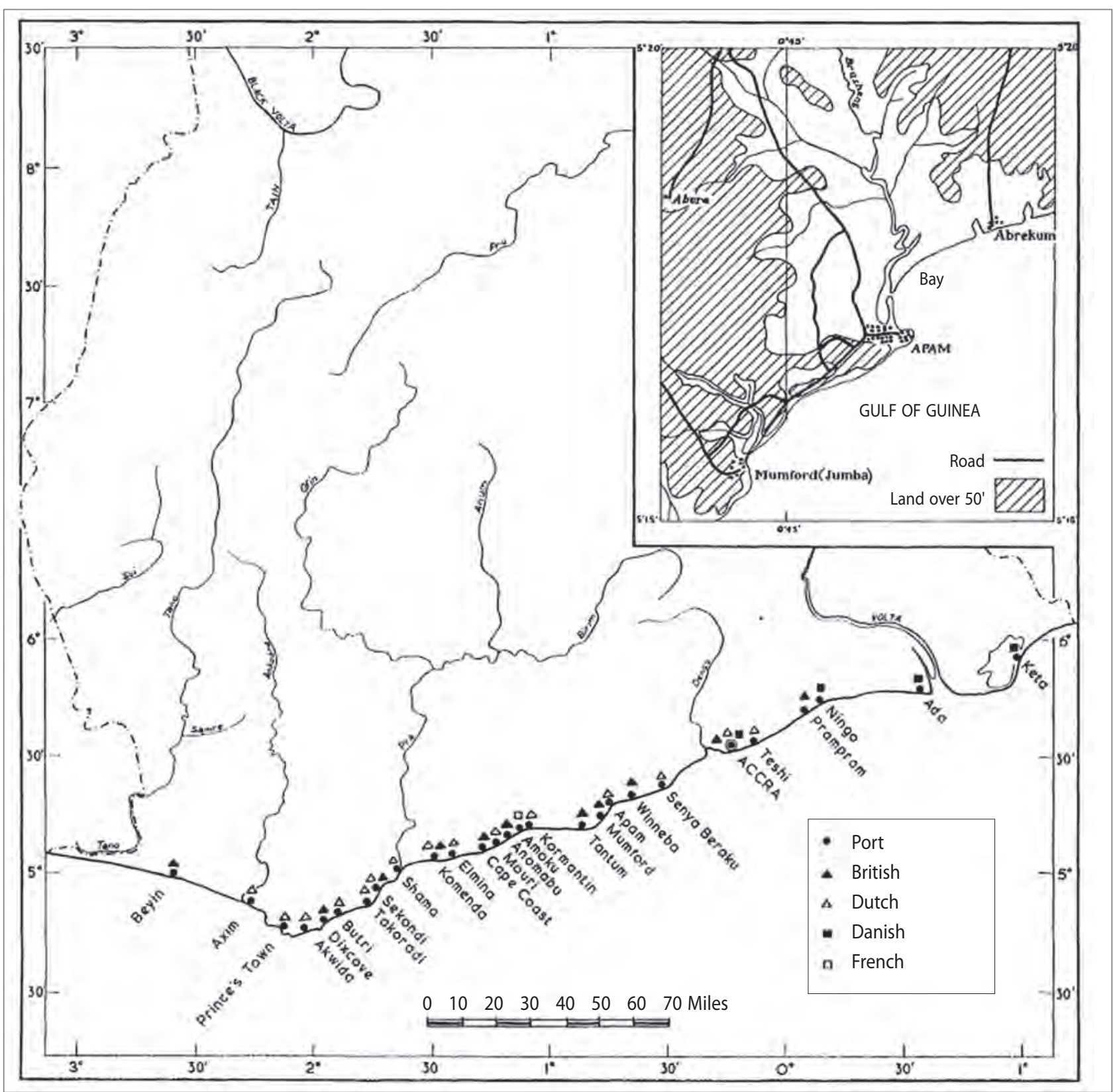

Figure 1: Ports in the Gold Coast, 1800 (source: Dickson, 1965). 


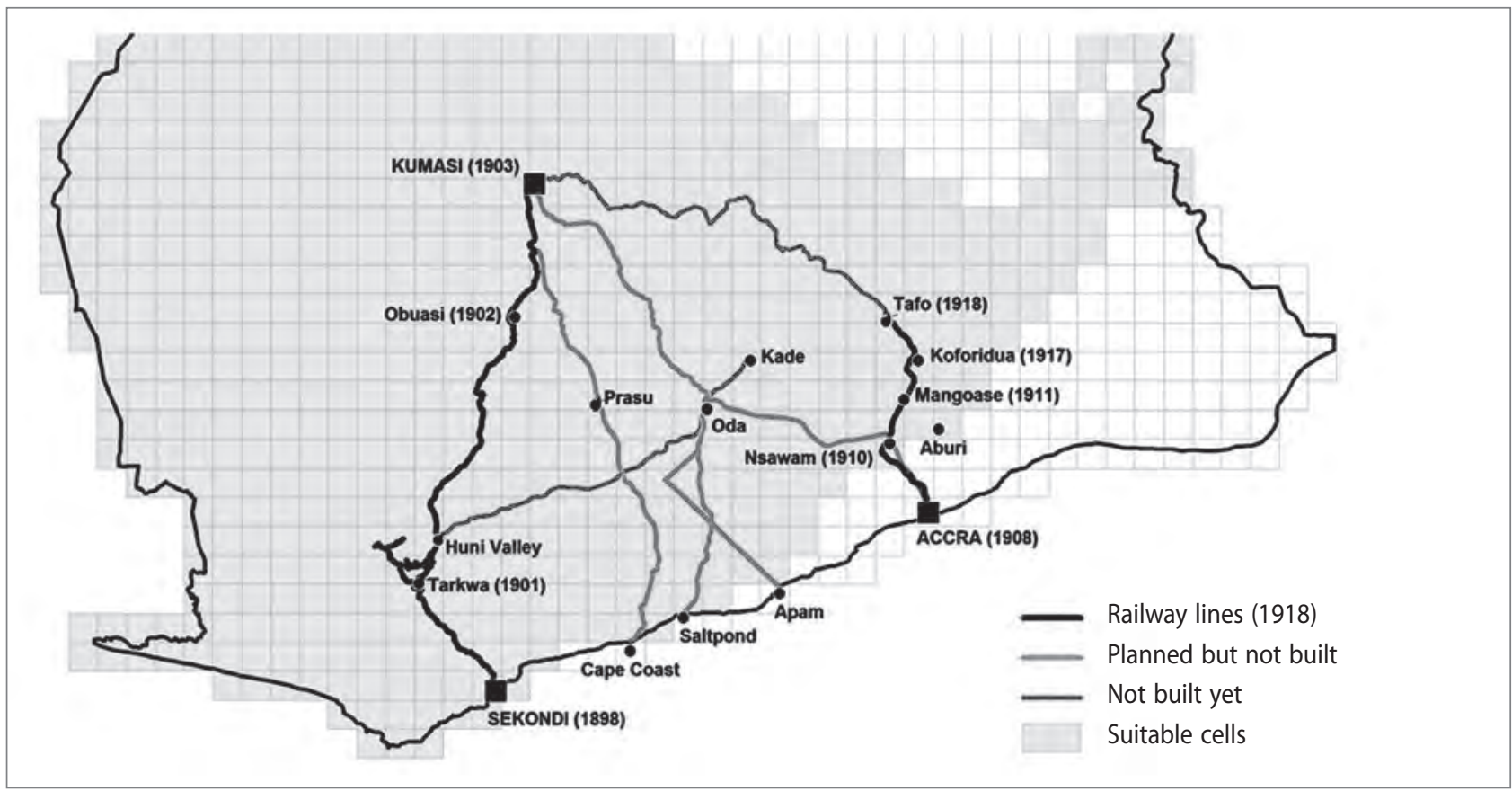

Figure 2: Railway lines, 1918 (source: Jedwab \& Moradi, 2011)

Nevertheless, it was ports, harbours and railways that contributed more substantially to the rise and importance of Sekondi-Takoradi (Busia, 1950). Around 1903, the potential of Takoradi as a harbour city was discovered by a Polish Jew named Lefeber, who planned to unleash that potential. $\mathrm{He}$ discussed his interest with the chief of Takoradi, the custodian of the land, who agreed to lease the entire foreshore of Takoradi to Lefeber together with much of the land behind it. In exchange, Lefeber paid a monthly rent of GBP 10. In addition, he donated a case of gin to the chief every month. Lefeber left the Gold Coast, but his successor continued to pay the rent and make the donation in the hope that a harbour could eventually be developed in Takoradi. In contrast, the colonial government focused its attention on trying to develop a harbour in neighbouring Sekondi (Correspondent, 1943).

Sekondi is older than Takoradi. The Sekondi Takoradi Metropolitan Assembly (2006) suggests that Sekondi had already emerged as a town as early as 1894 . Takoradi was recognised as a "town" much later, in 1926 (Busia, 1950), and had no reputation. One article (Correspondent, 1943: 38) reported "Takoradi ... to be a small collection of dirty reed and thatch huts where the beach ended and the bush began". Around 1913, the payment of the monthly rent was discontinued because the lessees no longer believed that Takoradi would ever become the home of a harbour (Correspondent, 1943). However, a harbour was built in Takoradi in 1928 as part of the 10-year plan of Gordon Guggisberg, governor of the Gold Coast at the time (Mendelson et al., 2003). Takoradi Harbour became West Africa's first artificial harbour (Hilling, 1975), complementing the role of the numerous ports in the Gold Coast (see Figure 1).
An important feature of the Takoradi Harbour was that it was served mainly by rail. That is, most of the goods sent to the port were carried by rail, which was developed much earlier in Sekondi. The first railway lines were built in 1898 to connect the gold-mining towns of Tarkwa (1901) and Obuasi (1902), a distance of 39 and 124 miles, respectively. Later, the lines were extended to Kumasi (1903). Other railway lines began from elsewhere, such as Accra, in 1905. Branch lines from Sekondi-Takoradi, such as the line from Tarkwa to Prestea, were built in 1911. By 1915, Sekondi had grown considerably, mainly as a commercial hub where some 490 miles of railways converged (Busia, 1950; see Figure 2). In 1928, the harbour in Takoradi was connected to Sekondi by a double line of track (Busia, 1950).

The harbour and rail facilities had significant effects on the development of Sekondi-Takoradi. They attracted migrants to the city, most of whom became permanent residents (Jeffries, 1975). The rail system greatly enhanced cocoa production (Jedwab \& Moradi, 2011). Sekondi-Takoradi, Kumasi and Accra, shown in Figure 2, collectively generated so much wealth and opportunities around rail transport that they were nicknamed the "Golden Triangle" (Owusu, 1998: 8). Altogether, $70 \%$ of logs, $44 \%$ of sawn timber and $40 \%$ of cocoa was transported to the harbour by rail in 1975 . As shown in Figure 3, port traffic was substantial. It provided $75 \%$ of the cargo carried by the railway system. In the 1970 s, the unloading rate in Takoradi was the second highest in West Africa (Hilling, 1975).

Between 1938 and 1939, exports from Takoradi increased by $186 \%$ and imports through the harbour soared 


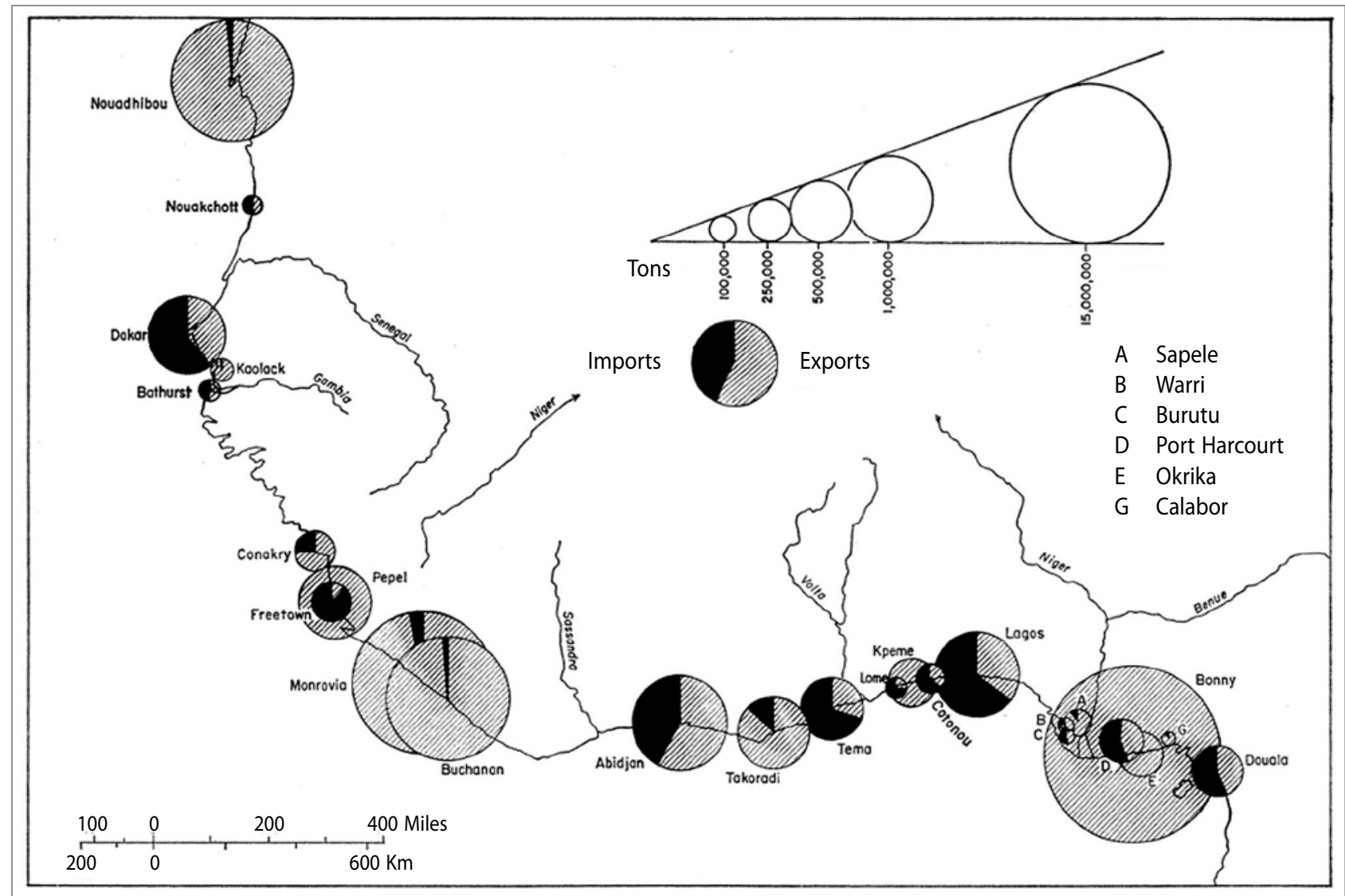

Figure 3: Imports and exports in selected West African ports, 1962-1967 (source: Hilling, 1969).

by $133 \%$ (White, 1955). Extension works were carried out at Takoradi Harbour around the time and ended in 1956, significantly increasing its carrying capacity from 2 to 3 million tonnes per year (Hilling, 1975). Even when Tema Harbour was developed later in 1962 - to serve the areas close to Accra and to ease some of the pressure on Takoradi owing to ongoing work on the construction of the Akosombo Dam (Hilling, 1969) - Takoradi Harbour remained the harbour of choice for most national exports. So, in 1972, for example, it was the exit point of $80.4 \%$ of total dry exports from the country (Hilling, 1975).

Harbour workers, according to Busia (1950), earned between GBP 2210 s and GBP 1,000 per annum in 1947, working from 6 (or 8) am to around 4 (or 6) pm. Outside these times, it was common practice among workers in the country to seek extra income elsewhere (Hart, 1973). Beyond work in and around the harbour, there were many formal and informal markets in the city where the workers could earn extra income through various activities. A prominent example was the $\mathrm{Ta}$ koradi "Market Circle", located in the central business district, and to this day regarded as "the most organized market circle in Ghana". It was built in 1960 and substantially expanded in the 1970s (ENNIMIL, 2011).
In spite of its economic prominence, Sekondi-Takoradi faced serious socioeconomic problems, prominent among which were insufficient food, inadequate housing and juvenile delinquency. Agriculture was a major employer in the urban economy, and fishers, hunters and farmers were quite common in the city (Mendelson et al., 2003). Yet the city typically imported its food (Busia, 1950), and the rate of new housing construction was significantly lower (163\%) than the rate of population growth (264\%) in 1970. Indeed, by 1984, the rate of housing development had declined drastically to $15.5 \%$ (see Table 1 ).

Not only was housing numerically inadequate, it was also inadequate in terms of quality. Only about $17 \%$ of the houses in 1950 had private toilets, and landlords were converting latrines and kitchens into spaces that they could rent out. In addition, there was overcrowding in rooms and homes. Moreover, some houses lacked appropriate cooking facilities and, where traditional kitchens were available, they lacked storage facilities (Busia, 1950).

As the city expanded, juvenile delinquency increased too. Society was becoming complex and a large number of juveniles were regularly brought before the juvenile courts. Did these constitute evidence of anomie? Probably, but their causes could hardly be traced to just one sudden change. Long work hours, separation of parents, breakdown of the extended fam- 
Table 1: Population characteristics of the Sekondi-Takoradi area ${ }^{[2]}$ in 1948, 1970 and 1984

\begin{tabular}{llll}
\hline Characteristics & 1948 & 1970 & 1984 \\
\hline Population & $44,130^{*}$ & 160,868 & 178,257 \\
\hline Houses & $3,996^{* *}$ & 10,507 & 12,099 \\
\hline
\end{tabular}

Note: $\left(^{*}\right)$ Excluding 807 non-African population; $\left(^{* *}\right)$ Figure refers to 1947.

Sources: Busia (1950); CHF International (2010); Ghana Statistical Service (1989, 2005, 2012); Consortium (2011).

ily, the need for (but lack of) regulations to cater for new dynamics and the creeping influence of capitalist production all contributed to delinquency. In turn, many children and youth began to fend for themselves by gambling and stealing, and sleeping in front of shops and in corridors in the market. Related problems of crime, prostitution and corruption were also evident, as were problems of quarrelling, fighting and unemployment (Busia, 1950). Indeed, some historians (e.g., Tait, 1951) have questioned the validity of the extent of these historical claims. Further, they occurred because the Takoradi Police Station was late in coming into existence (1975) and its jurisdiction over major crime areas was established late in the 1980s (Owusu, 2010), rather than because of "anomie" or a "resource curse".

\section{Political governance, consciousness and agitation}

Turning to questions of politics, the political governance of Sekondi-Takoradi was primarily the responsibility of the Sekondi Town Council. It was established in 1903 under the Town Council Ordinance. In 1943, the D. A. Sutherland committee was set up to consider the possibility of merging Takoradi and Sekondi. The committee strongly recommended a merger in its report submitted in 1944. On 2 December 1946, Takoradi and Sekondi were merged politically and administratively as the Sekondi-Takoradi Town Council, with Sekondi as the capital. In 1954, 3 years before the country gained political independence from Britain, the council was made a municipality because its population had grown substantially. Similarly, by 1988 , the population had grown so significantly that the municipality was elevated to the rank of metropolitan area, operating under the Local Government Law, 1988, PNDCL 207 (Sekondi Takoradi Metropolitan Assembly, 2006). Two other institutions assisted the Town Council in governing the city. The Native Authority, made up of chiefs and their councils nominated/elected based on familial, lineage and clan lines; and the central government authority (Busia, 1950).

Table 2: Formal public sector workers, 1947

\begin{tabular}{ll}
\hline Department & Employees \\
\hline Gold Coast Railways & 3,276 \\
\hline Medical (Health) Dept. (Sekondi and Takoradi) & 797 \\
\hline Public Works Dept. (Sekondi) & 654 \\
\hline Takoradi Harbour & 507 \\
\hline
\end{tabular}

Source: Busia (1950).
The duties of these bodies differed and were often informed by ordinances; namely, the Native Authority Ordinance (1944), the Native Courts Ordinance (1944) and the Sekondi-Takoradi Town Council Ordinance (1945). The Native Authority exercised legislative, judicial and spiritual responsibilities, for which reason it was allowed to collect various taxes and duties. Significantly, it exercised its powers only over people of African descent. The Town Council was rather different. With a broader representation, every race was subject to its powers, which were mainly legislative, executive and administrative. The council ensured that the people in the municipality were healthy by providing them with sanitation services and healthcare facilities. It regulated business activities and building operations, and supplied other municipal services. The colonial central government had overwhelming powers in managing the municipality. It had the final say and decided whether a customarily nominated/elected and installed chief could, in fact, work in the Native Authority (Busia, 1950).

Regarding political consciousness, the railways sector was its vanguard. The railway workers repeatedly staged demonstrations to demand improved working conditions for themselves and other workers. Most of the members of the Railway Workers' Union (R.W.U) lived in Sekondi-Takoradi, where the R.W.U was headquartered. The workers could broadly be categorised into two groups: those in their 20 s and 30s, and older people. The former were typically more interested in ensuring the fair distribution of resources in society, and the latter usually focused more on internal politics of the union and the workplace (Haynes, 1991).

According to Busia (1950), railway workers constituted the single most populous group among formal sector workers' associations in 1947 . They were more $(3,276)$ than the total number of workers in the private formal sector $(3,050)$ and more than workers in any government department, as shown in Table 2.

The railway workers had significant influence on political agitation and the nature of politics in the Gold Coast. Indeed, it is widely believed that their activities contributed substantially to the removal of the Progress Party government (1969-1972) from office (Haynes, 1991). The leader of the R.W.U, Pobee Biney, who doubled as a leading member of the Convention People's Party (CPP) persuaded Kwame Nkrumah, leader of the CPP, to call for "positive action" on 9 January 1950. By 
"positive action", Pobee Biney meant a period during which all workers in the Gold Coast would boycott British shops and stay home from work. The motive was to force imperial Britain to grant the colony independence (Crisp, 1979; Ministry of Education, 1991). Nkrumah acceded to his request, catalysing other efforts to attain political independence.

The struggle for independence was closely related to the role of Takoradi in imperial Britain's effort to defeat the Vichy state - the French state that supported Italy, Japan and Germany, collectively known as the Axis Powers (Parker, 2005). In the lead-up to the Second World War, around 1936, imperial Britain converted the small airport in Takoradi, established by (British) Imperial Airways, to military purposes (Jackson, 2006: 218). The Takoradi Airport was used as a strategic royal air base where British planes took off for North Africa and the Middle East to ward off Italian advances to the British Empire (Akyeampong, 2003). Between August 1940 and June 1943, more than 4,500 British airplanes were assembled in Takoradi (Jackson, 2006). Subsequently, Royal Air Force training schools were established in Takoradi. The American army also used the services of the airport as a "portal to a major allied trans-African supply line" or, officially, as a major point in the West African Reinforcement Route (Jackson, 2006: 225).

The creation of the Royal West African Force was an additional level of support extracted by Imperial Britain from its colonies in West Africa. That is, in addition to the use of the airport, a number of people in Takoradi were recruited into the Royal West African Frontier Force with a total enlistment of 65,000 Ghanaians (Israel, 1987; Jackson, 2006). Although imperial Britain declared triumphantly that "African soldiers beat the Italians ... They defended British West Africa from attack from Vichy territory ... and went to the Middle East as Pioneers and to the Far East to fight Japan" (Jackson, 2006: 171), the ex-service people began to feel it was time for their "independence" and the liberation of their country (the Gold Coast) from the clutches of colonialism.

Many reasons account for this anti-colonial feeling. The ex-servicemen complained that they were paid less than the British officers. They were also mistreated and discriminated against, although they felt they were as brave as the British in the army. According to one ex-serviceman, he had seen a British officer "panting for breath and shouting for whisky" in the face of an attack, while a soldier from the Gold Coast had skilfully and bravely taken charge (Israel, 1987: 163). Moreover, they felt that the infrastructure in some of the other colonies that they had seen during the war was better, in terms of both quantity and quality (Israel, 1987). In turn, the ex-soldiers started agitating for independence and encouraging others to fight it. As one veteran in Takoradi put it:
In the array, the white people were not treating most of us well. They were kicking us, calling us "you black monkey", and so forth. We didn't like the way they were treating us, especially when we went to Burma and all those places. So there we even decided to do something for ourselves when we came back. (Israel, 1987: 160)

Together with other local factors, national, regional and international forces contributed to the attainment of political independence on 6 March 1957 (for a general account, see de Smith, 1957). After independence, the railway workers resisted attempts to deradicalise and control the union. As part of the post-independence resistance, a 17-day strike was called in September 1961 (Crisp, 1979). The union was characterised by "labour aristocracy", a phenomenon of social differentiation among the labour class, but it retained a united front. Its activities further strengthened the identity of Sekondi-Takoradi as a working-class city (Jeffries, 1975). However, with time, the cumulative effect of lack of investment in the railway system, institution of government-sponsored parallel unions (the Ghana Trades Union Congress, in particular), the delinking of the administration of ports from the railways, and the substantial expansion of road transport left the R.W.U. weak (Haynes, 1991). Indeed, after the 1966 coup d'etat in Ghana, culminating in the freedom of the Ghana Trades Union Congress (GTUC) from governmental control, the fulcrum around which workers organised shifted to the GTUC (see Goldsworthy, 1973) headquartered in Accra, and the GTUC is still the biggest labour union in Ghana to this day.

\section{Whither Sekondi-Takoradi?}

The discovery of oil brought renewed energy to the city in 2007. Today, the "oil city" remains a site characterised by a mixture of "old" and "new" urban forms. Old houses coexist with modern residential facilities, as is the case elsewhere in Ghana (Obeng-Odoom \& Amedzro, 2011) and, as shown in Figure 4, formal markets exist side-by-side with informal ones.

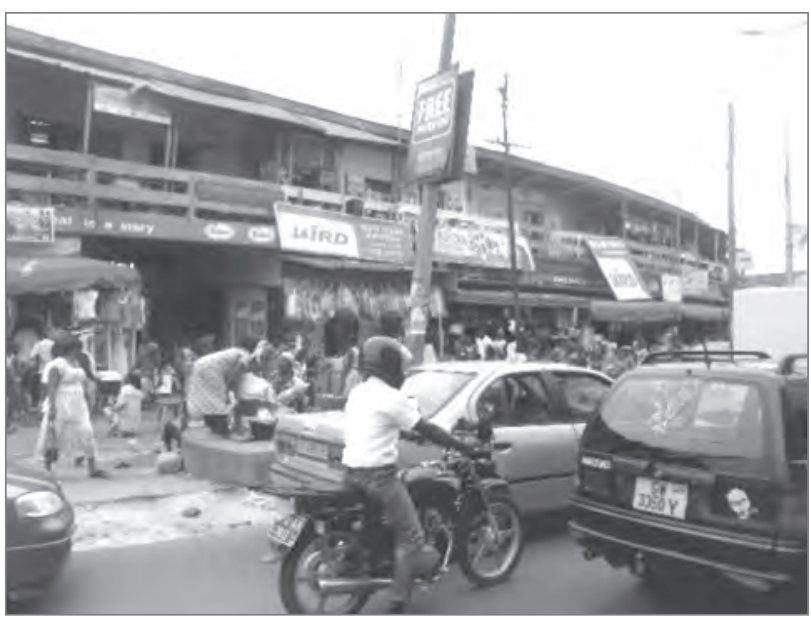

Figure 4: A mixture of formal and informal economic activities in the Market Circle Area, August 2012 (photo: Frank Opoku) 
Table 3: Volume of and revenue from the oil sector (Jubilee field) in Ghana

\begin{tabular}{llll}
\hline Year & Volume (barrels) & Revenue (USD) & Jobs \\
\hline 2011 & $24,451,452$ & $444,439,138.8$ & $/$ \\
\hline 2012 (Projected) & $32,850,000$ & $826,546,666.67$ & $3,500^{*}$ \\
\hline
\end{tabular}

Notes: $\left(^{*}\right)$ Total jobs created since 2007.

Sources: Ministry of Finance and Economic Planning (2011); Ministry of Information (2012).

It is widely anticipated that these features will undergo major transformations. The city as a whole is expected to suffer "anomie", "resource curse" or the "rentier state" phenomenon. However, the historical analysis shows that such pessimism will have to be more nuanced. Indeed, in contrast to such determinisms, there seem to be some economic gains, as shown in Table 3.

In addition to the economic gains described in Table 3 , it is estimated that the related gas industry is worth USD 260 million a year (World Bank, 2009). The city is also bustling with transnational activities. Since 2007, at least 41 global resource corporations have been involved in the oil industry in the city. These interests come from across the world, including the U.S., Norway, the UK, Australia, China and Russia (Obeng-Odoom, 2012b). Furthermore, "King City", a satellite settlement on 2,400 acres of land in Takoradi, is being planned over the next 10 years for 160,000 people. However, it is crucial to study the impact of these transformations on local livelihoods and ascertain fault lines of contradictions.

For the political and business elite in Ghana, the development of a King City, which will potentially create a large reservoir of migrants, will be socially positive and beneficial for the people of Sekondi-Takoradi and Ghanaians generally. According to the $\mathrm{CEO}$ of the Renaissance Group, the vision of his company is to create state-of-the art facilities in King City. Further, "Ghana's powerful combination of a dynamic economy and business-friendly environment will allow it to create solutions to rapid urbanisation and demographic growth faster than many countries in the world" (Baidoo, 2012). However, if the experiences of other boomtowns and quasi-resource centres in Africa, such as the Copperbelt in Zambia (Ferguson, 1990a, 1990b, 2005), Kano in Nigeria (Maconachie et al., 2009), Gaborone in Botswana (Kent \& Ikgopoleng 2011) and Kataroo in Tanzania (Bryceson, 2011), are anything to go by, the claims of the $\mathrm{CEO}$ should not be taken at face value. Oil exploration and development can create new avenues of accumulation, but also dispossession. These developments cannot be lumped together as "resource curse", "social disruption" or "anomie".

Similarly, while the political polarisation of the country along party lines and the danger that it can intensify as oil rents begin to shape politics suggest that there may be nepotism and favouritism in the allocation of jobs in the oil industry in Sekondi-Takoradi, concluding that they foretell a "rentier state" phenomenon is misleading. True, there are troubling telltale signs, such as the negotiation of loan facilities (e.g., USD 3 billion from China Development Bank), apparently in breach of the provisions of the existing Petroleum Revenue Management Act of 2010, haste in executing agreements (e.g., an agreement with STX Engineering and Construction Services Ltd based in Korea to build 200,000 units of housing, which have turned out to be stillborn), and the training and inauguration of a special military force ostensibly to protect the oil reserves in Sekondi-Takoradi but possibly to be used to contain and intimidate people critical of the government (Gyimah-Boadi \& Prempeh, 2012). However, there is also considerable civil-society oversight in the oil industry in Sekondi-Takoradi. Currently, over 110 civil-society groups are involved in scrutinising oil deals. Furthermore, there are over 150 private FM radio stations, 20 TV stations and some 114 internet service providers, all of which have shown interest in the management of oil revenues for the benefit of the majority of the people in Ghana (Gyimah-Boadi \& Prempeh, 2012). Thus, there is cause to be simultaneously upbeat and downbeat about Sekondi-Takorad's oil industry.

\section{Conclusion}

Some 100 years ago, West Africa's newest oil city was nothing but a collection of streets of huts. It had no clearly visible signs of influence or affluence. In turn, the "owners of the city" obtained a few bottles of gin and a small amount of pounds sterling from foreign interests for the use of large portions of the city. However, with the passage of time, the development of harbour and rail facilities combined with worker activism catapulted Sekondi-Takoradi to national and international importance. From this perspective, the recent development of the oil industry and the attendant local, regional and international interest seem to have a historical parallel. Sekondi-Takoradi has come full circle. It has seen this vibrancy before, although the post-2007 oil industry introduces new challenges and opportunities related to the development of land, labour and capital. In any case, as in the case of the railway workers, oil workers may unionise and this, in turn, would have a great influence on the city's economy, society and environment. Social relations are likely to become increasingly complex and new contours of adjustment and maladjustment may arise, but they will not necessarily cause "social disruption", a "resource curse" or "rentier state" pressures. Institutions - formal, informal, im- 
plicit and explicit - and rules, processes and customs matter: they shape, restrain and constrain the future, as studying the political economic past of Sekondi-Takoradi has shown.

Franklin Obeng-Odoom

University of Technology, Sydney, School of the Built Environment, Sydney, Australia

E-mail: Franklin.Obeng-Odoom@uts.edu.au,odoomj6@yahoo.co.uk

\section{Notes}

[1] The name of modern Ghana before 6 March 1957.

[2] The "Sekondi-Takoradi Area" came into being in 1946 as a "town council". In 1954, it became a municipality and in 1988 a metropolitan area, signalling the growing population of the area (Busia, 1950; Sekondi Takoradi Metropolitan Assembly, 2006).

\section{Acknowledgements}

Thanks to the reviewer for Urbani izziv for comments that helped improve the quality of this paper, and to Boštjan Kerbler, the editor of the journal, for editorial support. Special thanks to H. S. Jang for assistance with improving the quality of the digital images and to Frank Opoku for providing Figure 4. The interpretation and analysis in the paper are entirely my own.

\section{References}

Administrators (2012) Colonial history (Sekondi-Takoradi). Available at: http://www.ghanaoilcity.com (accessed 11 Jul. 2012).

Akyeampong K. E. (2003) Review of soldiers, airmen, spies and whisperers: The Gold Coast in World War II. Journal of Military History, 67(3), pp. 971-972. DOI: 10.1353/jmh.2003.0191

Baidoo, J. (2012) Veep unveils prototypes of two cities. Daily Graphic, 9 Jul. 2012. Available at: http://www.graphic.com.gh (accessed 14 Jul. 2012).

Beblawi, H. (1987) The rentier state in the Arab world. In: Beblawi, H. \& Luciani, G. (eds.) The rentier state, pp. 49-62. North Ryde, NSW, Istituto Affari Internazionali.

Boohene, R., \& Peprah, J. A. (2011) Women, livelihood and oil and gas discovery in Ghana: An exploratory study of Cape Three Points and surrounding communities. Journal of Sustainable Development, 4(3), pp. 185-195. DOI: 10.5539/jsd.v4n3p185

Bryceson, D. (2011) Birth of a market town in Tanzania: Towards nar rative studies of Urban Africa, Journal of Eastern African Studies, 5(2), pp. 274-293. DOI: 10.1080/17531055.2011.571389

Busia K. A. (1950) A report on a social survey of Sekondi-Takoradi. London, Crown Agents for the Colonies for the Govt of the Gold Coast.

CHF International (2010) Sekondi-Takoradi poverty map: A guide to urban poverty reduction in Sekondi-Takoradi. Accra.

Collier P. (2009) The bottom billion: Why the poorest countries are failing and what can be done about it. New York, Oxford University Press.

Consortium, The (2011) Interim report: The preparation of Sekondi-Takoradi Structure Plan. Accra.

Corden W. M. \& Neary J. P. (1982) Booming sector and de-industrialisation in a small open economy. The Economic Journal, 92(368), pp. 825848. DOI: $10.2307 / 2232670$
Correspondent (1943) Takoradi: A memory. Scottish Geographical Magazine, 59(1), pp. 37-38.

Crisp, J. (1979) Review of "Class power and ideology in Ghana: The railway of Sekondi". Review of African Political Economy, 14(Jan.-Apr.), pp. 111-113.

De Smith, A. S. (1957) The independence of Ghana. The Modern Law Review, 20(4), pp. 347-363. DOI: 10.1111/j.1468-2230.1957.tb00448.x

Dickson, K. B. (1965) Evolution of seaports in Ghana: 1800-1928. An nals of the Association of American Geographers, 55(1), pp. 98-111. DOI: 10.1111/j.1467-8306.1965.tb00508.x

Durkheim, E. (1951) Suicide: A study in sociology. Glencoe, IL, Free Press

Edem R. (2011) The expected impact of the oil discovery in Takoradi on land use patterns and growth of the city. Bachelor's dissertation. Accra, Kwame Nkrumah University of Science and Technology, Department of Planning.

ENNIMIL (2011) Takoradi market structure is fallen apart. ENNIMIL News File. Available at: http://ennimil.blogspot.com.au (accessed 13 Jul. 2012).

Ferguson J. (1990a) Mobile workers, modernist narratives: A critique of the historiography of transition on the Zambian Copperbelt, part one. Journal of Southern African Studies, 16(3), pp. 385-412. DOI: $10.1080 / 03057079008708243$

Ferguson J. (1990b) Mobile workers, modernist narratives: a critique of the historiography of transition on the Zambian Copperbelt, part two. Journal of Southern African Studies, 16(4), pp. 603-621. DOI: $10.1080 / 03057079008708253$

Ferguson J. (2005) Seeing like an oil company: space, security, and global capital in neoliberal Africa. American Anthropologist, 107(3), pp. 377-382. DOI: 10.1525/aa.2005.107.3.377

Gay, E. F. (1930) Historical records. The American Economic Review, 20(1), pp. 1-8.

Ghana Statistical Service (1989) 1984 Population and housing census. Accra.

Ghana Statistical Service (2005) 2000 Population and housing census. Accra.

Ghana Statistical Service (2012) 2010 Population and housing census. Accra.

Goldsworthy, D. (1973) Ghana's second republic: A post mortem. African Affairs, 72(286), pp. 8-25.

Greif, A. (1998) Historical and comparative institutional analysis. The American Economic Review, 88(2), pp. 80-84.

Gyampo, V. R. E. (2011) Saving Ghana from its oil: A critical assessment of preparations so far made. Africa Today, 57(4), pp. 50-69.

Gyimah-Boadi, E. \& Prempeh, H. K. (2012) Oil, politics, and Ghana's democracy. Journal of Democracy, 23(3), pp. 94-108. DOI: 10.1353/ jod.2012.0042

Hart, K. (1973) Informal income opportunities and urban employment in Ghana. Journal of Modern African Studies, 11(1), pp. 61-89. DOI: $10.1017 /$ S0022278X00008089

Haynes, J. (1991) Railway workers and the P.N.D.C government in Ghana, 1982-90. The Journal of Modern African Studies, 29(1), pp. 137-154. DOI: $10.1017 / \mathrm{S} 0022278 \times 00020772$

Hilling, D. (1969) The evolution of the new ports of West Africa. The Geographical Journal, 135(3), pp. 365-378. DOI: 10.2307/1797325

Hilling, D. (1975) Port specialization and efficiency - The case of Ghana. Maritime Studies and Management, 3(1), pp. 13-20. DOI: 10.1080/03088837500000003

Israel, A. M. (1987) Measuring the war experience: Ghanaian soldiers in World War II. The Journal of Modern African Studies, 25(1), pp. 159-168. DOI: $10.1017 /$ S0022278X00007667 
Jackson, A. (2006) The British Empire and the Second World War. New York, Hambledon Continuum.

Jedwab, R. \& Moradi, A. (2011) Transportation infrastructure and development in Ghana (= Working Paper No. 2011 - 24). Paris, Paris School of Economics.

Jeffries, R. (1975) The labour aristocracy? Ghana case study. Review of African Political Economy, 2(3), pp. 59-70. DOI: $10.1080 / 03056247508703257$

Kapela, J. M. (2009) Ghana's new oil: Cause for jubilation or prelude to the resource curse. Master's dissertation. Durham, NC, Nicholas School of the Environment, Duke University. Typescript.

Kent, A. \& Ikgopoleng, H. (2011) City profile: Gaborone. Cities, 28(5), pp. 478-494. DOI: 10.1016/j.cities.2010.11.004

Lawrie, M., Tonts, M. \& Plummer, P. (2011) Boomtowns, resource dependence and socio-economic well-being. Australian Geographer, 42(2), pp. 139-164. DOI: 10.1080/00049182.2011.569985

Maconachie, R., Tanko, A. \& Zakariya, M. (2009) Descending the energy ladder? Oil price shocks and domestic fuel choices in Kano, Nigeria. Land Use Policy, 26(4), pp. 1090-1099. DOI: 10.1016/j.landusepol.2009.01.008

Mahama, F. (2012) Study of vehicular traffic congestion in the SekondiTakoradi metropolis. Master's dissertation. Kumasi, KNUST, Department of Mathematics.

Marcuzzo, M. C. (2008) Is history of economic thought a "serious" subject? Erasmus Journal of Philosophy and Economics, 1(1), pp. 107-123.

McCaskie, T. (2008) The United States, Ghana and oil: Global and local perspectives. African Affairs, 107(428), pp. 313-332. DOI: 10.1093/afraf/ adn019

Mendelson, S., Cowlishaw, G. \& Rowcliffe, J. M. (2003) Anatomy of a bushmeat commodity chain in Takoradi, Ghana. Journal of Peasant Studies, 31(1), pp. 73-100. DOI: 10.1080/030661503100016934

Ministry of Education (1991) History for Senior Secondary School. Accra.

Ministry of Finance and Economic Planning (2011) 2011 budget. Accra.

Ministry of Information (2012) Overview of the Better Ghana Agenda.

Accra.

Obeng-Odoom, F. (2009) Oil and urban development in Ghana. African Review of Economics and Finance, 1(1), pp. 18-39.

Obeng-Odoom, F. (2012a) Natural resource abundance and eminent domain: A study from Africa. Local Economy, 27(4), pp. 319-325. DOI: $10.1177 / 0269094212439174$

Obeng-Odoom, F. (2012b) Problematising the resource curse thesis. Development and Society, 41(1), pp. 1-29.

Obeng-Odoom, F. \& Amedzro, L. (2011) Nezadostno število in neustrezna kakovost stanovanj v Gani [Inadequate housing in Ghana]. Urbani izziv, 22(1), pp. 49-59 [127-137]. DOI: 10.5379/urbani-izziven-2011-22-01-004

Owusu, H. J, (1998) Adjustment, industrial locational incentives, and structural transformation in Ghana. East African Geographical Review, 20(2), pp. 1-24. DOI: 10.1080/00707961.1998.9756264

Owusu, K. (2010) Design and production of suggestion box for the various departments in Takoradi Polytechnic. Report submitted to the Department of Graphics, Takoradi Polytechnic, in partial fulfilment of the requirements for the award of the HND in Commercial Art, Takoradi, Ghana. Typescript.

Parker, J. (2005) Next door to Vichy. Soldiers, airmen, spies, and whis perers: The Gold Coast in World War II. The Journal of African History, 46(3), pp. 529-531.
Sekondi Takoradi Metropolitan Assembly (2006) About this metropolis. Brief history. Available at: http://stma.ghanadistricts.gov.gh (accessed 24 Jun. 2012)

Tait, D. (1951) Review of report on a social survey of Sekondi-Takoradi. Man, 51(Dec.), p. 172.

Tuma, E. H. (1971) Economic history and the social sciences: Problems of methodology. Berkeley, University of California Press.

White, H. P. (1955) Port developments in the Gold Coast.

Scottish Geographical Magazine, 71(3), pp. 170-173.

DOI: $10.1080 / 00369225508735616$

Wilkinson, K., Reynolds, R, Thompson, J. \& Ostresh, J. (1982) Local social disruption and western energy development: A critical review. Pacific Sociological Review, 25(3), pp. 275-296. DOI: 10.2307/1388767

World Bank (2009) Economy-wide impact of oil discovery in Ghana. Washington, DC.

Yalley, P P. \& Ofori-Darko, J. (2012) The effects of Ghana's oil discovery on land and house prices on communities nearest to the oil filed in Ghana (Case Study: Kumasi and Sekondi-Takoradi). Paper presented at the 4th West Africa Built Environment Research (WABER) Conference, 24-26 July 2012, Abuja, Nigeria. Typescript. 